\title{
Penerapan Metode TPR (Total Physical Respone) Dalam Pembelajaran Bahasa Inggris Anak Usia Dini
}

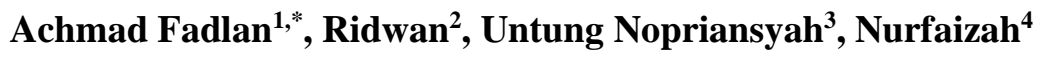 \\ ${ }^{1,2}$ Universitas Islam Negeri Sulthan Thaha Saifuddin Jambi, Indonesia \\ ${ }^{3}$ Universitas Islam Negeri Raden Intan Lampung, Indonesia \\ ${ }^{4}$ Universitas Islam Negeri Sunan Kalijaga Yogyakarta, Indonesia \\ *Fadlamsalsabilah@UINJAMBI.ac.id
}

\begin{abstract}
Abstrak
Lancar berbahasa inggris menjadi nilai plus dalam berinteraksi bahkan didunia kerja. Penggunaan metode yang tepat dapat membantu dalam pengenalan bahasa inggris khusunya pada anak usia dini. Penelitian ini bertujuan untuk mengetahui Penerapan metode (Total Physical Respone) Di Kelompok B TK Edelweiss Kota Jambi Ajaran 2018/2019. Beragam persoalan dan penanganannya. Metode Total physical respone diintoleran dengan maksud menstimulus peserta didik dalam mengembangkan bahasa inggris pada anak tk tersebut. Subjek penelitian ini 15 peserta didik, yang tersusun dari 3 anak laki-laki dan 8 anak perempuan. Berlandaskan perolehan observasi yang sudah dilaksanakan kepada 15 orang. Reaksi Peningkatan kemampuan bahasa anak tersebut diperoleh dari observasi nilai rata-rata kemampuan bahasa pra observasi perlakuan metode TPR $41,75 \%$ menjadi $59 \%$ pada siklus satu dengan kenaikan peningkatan rata-rata sebesar $49 \%$ dan menjadi $86 \%$ di siklus II dengan mengalami peningkatan rata-rata sebesar 76,25\% Hal ini menunjukkan implementasi cara TPR memperoleh peningkatan kemampuan berbahasa peserta didik. Penelitian Tindakan Kelas (PTK) adalah cara Kemmis dan M. Tanggrat, bersifat kualitatif dan kuantitatif. Perolehan nilai memberikan petunjuk akan perolehan memberikan adanya peningkatan Bahasa inggris pada AUD. Pada kegiatan ini dilakukan peneliti dengan dilakukan 2 siklus.
\end{abstract}

Kata Kunci: TPR (Total Physical Respone); bahasa inggris; anak usia dini

\section{Application Of TPR (Total Physical Respone) Method In Early Children's Learning English}

\begin{abstract}
Fluent in English is a plus in interacting even in the world of work. The use of the right method can help in the introduction of English, especially in early childhood. This study aims to determine the application of the method (Total Physical Response) in Group B TK Edelweiss, Jambi City Ajaran 2018/2019. Various problems and their handling. The total physical response method is intolerant with the aim of stimulating students in developing English in these kindergarten children. The subjects of this study were 15 students, consisting of 3 boys and 8 girls. Based on the acquisition of observations that have been carried out to 15 people. Reaction The increase in children's language skills was obtained from the observation of the average value of the pre-observational language ability of the TPR method treatment of $41.75 \%$ to $59 \%$ in cycle one with an average increase of $49 \%$ and to $86 \%$ in cycle II with an average increase. -An average of $76.25 \%$ This shows the implementation of the TPR method to improve the language skills of students. Classroom Action Research (PTK) is the Kemmis and M. Tanggrat method, qualitative and quantitative in nature. Earnings of scores provide an indication of the gains that give AUD an improvement in English. In this activity the researcher carried out two cycles.
\end{abstract}

Keywords: TPR (Total Physical Respone); english; early childhood 


\section{PENDAHULUAN}

Pendidikan merupakan kewajiban setiap orang baik laki-laki maupun perempuan untuk menunjang kehidupanya baik didunia maupun diakhirat. Bagi setiap individu pendidikan begitu penting untuk menunjang proses kehidupannya. Pendidikan bagian untuk menggali segala pengetahuan bagi setiap individu, pendidikan mengajarkan bagaimana norma-norma kehidupan di masyarakat. oleh karena itu pendidikan begitu penting bagi setiap individu. Pendidikan mengatur bagaimana cara hidup atau kehidupan di masyarakat. melalui indivudu yang mengemban pendidikan atau menempuh pendidikan akan menjadikan hidupnya bermartabat (Pratiwi et al., 2021).

Anak merupakan bagian dari masa pertumbuhan dan perkembanga. Anak adalah bagian dari hidup yang perlu di ajarkan Ketika hidup di masyarakat. anak merupakan anugrah yang di berikan oleh Tuhan untuk kita semua, anak terlahir dengan fitrahnya. Fitrah alamiah yang di berikan oleh allah harus di pupuk dengan optimal oleh orang tua dan pendidik (guru). Fitrah yang berkaitan dengan nilai agama, sosial, budaya, moral, seni dan kreativitas. Suyanto menyatakan bahwa usia awal kehidupan anak yang menentukan dalam perkembangan kecerdasannya adalah pada usia 0-8 tahun atau yang sering disebut dengan golden age (Suyanto S, 2005). Dimana perkembangan menunju pada suatu proses kearah yang lebih sempurna dan tidak begitu saja dapat diulang kembali. Pada masa ini perkembangan anak berada pada masa golden age atau masa keemasan, maksudnya adalah masa ini sangat penting untuk mengembangkan setiap aspek perkembangan anak, agar perkembangan anak berjalan dengan optimal. Pendidikan Islam Anak Usia Dini (PIAUD) dirancang secara khusus melalui metode bermaian sambal belajar. Belajar melalui kegiatan bermain mampu membuat konsentrasi anak lebih lama.

Anak usia dini memiliki karakter. Setiap anak memiliki karakter yang berbeda. Oleh karena itu anak usia dini memiliki sifat yang unik. Keunikan anak itulah yang perlu di pertahankan dengan cara mengoptimalkan segala bakat fitrah yang telah ada sejak lahir dan itu merupakan pemberian dan anugrah dari Tuhan yang maha kuasa. Anak usia dini memiliki karakteristik yang khas, baik secara fisik, psikis, sosial, moral, dan sebagainya (Rohmah, 2018). Anak usia dini merupakan sebuah anugerah pada mana akan berorientasi sesuai dengan potensinya dalam hal ini kapasitas ayah dan ibunya bagian dari factor penting 
Al Athfaal: Jurnal Ilmiah Pendidikan Anak Usia Dini

Vol.4 No.1 (2021) 137-151

p-ISSN : 2622-5484

http://ejournal.radenintan.ac.id/index.php/al-athfaal

mengembangkan potensi peserta diidk (Oemar Hamalik, 2010). Undang-Undang Republik Indonesia No. 23 Tahun 2002 Pasal 9 ayat 1, tentang perlindungan anak menyebutkan bahwa "setiap anak berhak memperoleh pendidikan dan pengajaran dalam rangka pengembangan pribadinya dan tingkat kecerdasannya sesuai dengan minat dan bakatnya" (Isjoni, 2009). Pemberian Pendidikan sejak awal pada anak adalah tahapan yang penting, dengan demikian pendidika anak usia memberikan tuntunan akan perolehan optimal di waktu selanjutnya (Dimyati dan Mudjiono, 2010).

Seorang individu haruslah memiliki pondasi dalam perkembangan yang diperankan melalui pendidikan yang harus ditempuhnya. sebagai angkatan penerus bangsa, dipundak merekalah kita akan menyerahkan kultur yang telah di bangun dan akan di tinggalkan (Kartini \& Sujarwo, 2014). Era awal anak adalah waktu krusial yan sungguh-sungguh membina kemampuan peserta didik. Sangatlah jelas di masa usia dini merupakapan era golden age / era keemasan, di waktu ini sangatlah tepat untuk pemberian rangsangan dalam berbagai aspek pada anak agar menjadikannya anak memiliki bekal akan segala hal yang perlu anak harus miliki. Tanpa sadar terkadang adanya suatu kegagalan awal yang berdampak pada diri anak yang memiliki rasa ketakutan, ketidak beranian bahkan rendahnya tingkat percaya diri anak bisa di sebabkan dari ke tidak leluasaan ketika ingin melakukan suatu hal yang terkadang tidak di sadari. Ketakutan yang menjadikan anak tidak percaya diri yang di alami oleh anak usia dini untuk menemukan sekaligus melakukan suatu hal yang baru bisa berdampak pada perkembangan dalam kehidupannya. Anak tidak berkembang kreativitaskanya dikarenakan adanya sebab yang salah satunya kurangnya stimulus yang akan berdampat menjadikan anak menjadi mempunyai rasa takut, tidak berani bahkan tidak percaya diri dalam melakukan suatu hal yang baru maupun sesuatu yang telah ada sebelumnya.

Hamalik mengutarakan pembelajaran adalah memperlancar interaksi antara guru dengan anak sehingga kegiatan pembelajaran lebih afektif dan efisien (Dewi, 2017). Pembelajaran yang baik merupakan pembelajaran yang memiliki komunasi dengan arah yang baik antara pendidika atau guru dan peserta didik. Pembelajaran adalah bagian dari proses pendidikan. pembelajaran yang merupakan kegiatan dalam memperoleh pengetahuan dengan segala bentuk maupun mekanisme yang ada yang telah di tetapkan. Guru berperan menyiapkan pembelajaran yang tepat bagi pekembangan anak usia dini. Perlunya metode maupun media yang relevan pada saat pembelajaran berlangsung dan dalam rangka 
Al Athfaal: Jurnal Ilmiah Pendidikan Anak Usia Dini

Vol.4 No.1 (2021) 137-151

p-ISSN : 2622-5484

http://ejournal.radenintan.ac.id/index.php/al-athfaal

pengoptimalan segala bakat unik anak yang akan atau ingin di kembangkan. Pembelajaran akan lebih efektif dan efisien ketika sedari awal telah memiliki perancanaan yang matang dan penuh pertimbangan sehingga tercapainya semua tujuan yang telah di rumuskan.

Demikian itulah perlu adanya ketepatan dalam pemilihan sebuah bentuk pembelajaran yang akan di berikan oleh pendidik kepada peserta didik. Hal itupun di maksudkan agar potensi yang sedang ingin di pupuk secara optimal akan bisa mencapai semua yang telah di inginkan dengan baik. Banyaknya bentuk perkembangan anak yang harus di kembangkan dengan optimal sejak usia dini yang berkaitan dengan fitrah anak itu sendiri adalah pada aspek perkembangan bahasa anak. Bahasa inggris adalah salah satu Bahasa yang sudah di pelajari di sekolah dalam mengemban Pendidikan. Bahasa inggris bisa menjadi suatu pertimbangan ketika ingin mengikuti sebuah ajang perlombaan bebricara dengan orang asing maupun ketika dewasa nanti dalam mencari perusahaan untuk bekerja. Ketika seorang anak sudah memiliki ke ahlian di bidang itu taklah sulit dalam berbicara dengan oarng asing (Herdyastika \& Kurniawan, 2020).

Dengan menguasai bahasa seorang anak mampu berkomunikasi dengan orang-orang disekitarnya baik dengan teman sebaya maupun orang dewasa, sehingga anak tersebut dapat memperoleh pengetahuan dari apa yang mereka dengar dan mereka ucapkan. Khususnya pada anak usia dini, kemampuan berbahasa dan berkomunikasi merupakan kebutuhan berbicara untuk awal proses di sekolah. Pembelajaran bahasa tidak hanya sebatas bahasa Indonesia (bahasa pertama) maupun bahasa kedua, namun juga ada bahasa asing yaitu bahasa Inggris. Di negara kita, Indonesia penggunaan bahasa asing sebagai bahasa sehari-hari bukanlah hal yang baru lagi meskipun hanya sebatas kata-kata sapaan (greetings) atau perpisahan (farewell) seperti contoh: good morning, how are you?, see you, good bye dan lain sebagainya. Bahkan bahasa Inggris juga masuk pada mata pelajaran di sekolah formal mulai dari Taman KanakKanak (TK) hingga Perguruan Tinggi. Berbicara tentang pelajaran bahasa Inggris di TK tentunya tidaklah mudah, hal ini dikarenakan mengajarkan bahasa Inggris pada Anak Usia Dini berbeda dengan mengajarkan bahasa Inggris untuk orang dewasa. Oleh karena itu, dibutuhkan kesabaran dan ketelatenan dari seorang guru dalam mengajarkan bahasa Inggris kepada anak. Salah satu metode yang digunakan untuk mengajarkan bahasa Inggris kepada anak usia dini adalah metode TPR (Total Physical Response). 
Al Athfaal: Jurnal Ilmiah Pendidikan Anak Usia Dini

Vol.4 No.1 (2021) 137-151

p-ISSN : 2622-5484

http://ejournal.radenintan.ac.id/index.php/al-athfaal

Pengenalan bahasa inggris untuk AUD dimulai dengan pemberianf kosakata sederhana dan pada dasarnya memiliki banyak manfaat yaitu anak mampu menguasai bahasa asing sehingga memiliki kelebihan dalam hal intelektual yang fleksibel, keterampilan akademik, berbahasa dan social, sehingga anak akan mempunyai kemampuan yang lebih baik untuk hidup ditengah masyarakat yang memiliki keberagaman social serta budaya.

Pada lembaga pendidikan, perkembangan baha Inggris terus di kembangkan. Di sekolahpun ada mata pelajaran Bahasa Inggris, dalam Pendidikan anak usia dinipun sudah di ajarkan kepada anak. Adanya pembelajaran Bahasa Inggris di sekolah yang mulai dengan di ajarkannya kosa kata Bahasa Inggris (vocabulary), dengan cara mendengarkan (listening), berbicara (speaking), dan menulis (writing) sejak usia dini sehingga nantinya dapat menguasai banyak kosa kata Bahasa Inggris.

Proses pembelajaran dalam Bahasa Inggris di pergunakan atau di manfaatkan sebagai media yang menjadi pendukung dari keterampilan aspek Bahasa anak usia dini. Melalui penguasaan dunia itu anak-anak nantinya akan mampu dan mudah berkomunikasi di dunia internasional. Sehingga ketika perlu berbicara dengan orang asing anak sudah mampu untuk bisa berbicara dengan menggunakan Bahasa inggris tersebut dengan baik dan lancar. Salah satu implikasi yang terlihat adalah semakin banyak orang berusaha belajar/menguasai Bahasa Inggris dengan baik karena melihat banyak sekali manfaat dari menguasai Bahasa Inggris seperti: 1) menambah pengetahuan, 2) mempermudah komunikasi dengan orang lain, 3) meningkatkan ke kepercayaan diri dengan dukungan media yang sesuai, 4) memudahkan diri untuk beradaptasi di lingkungan baru, 5) memudahkan diri untuk bergaul, dan masih banyak manfaat menguasai bahasa Inggris yang lainnya.

Bahasa merupakan bagian dari bentuk berkomunikasi. Bahasa erat kaitan dengan kosa kata. Kosa kata merupakan kata-kata yang di ucapkan ketika berbicara. Bahasa bagian dari berbicara dan itupun terucapkan dengan pola kosa kata. Kejelasan dalam berbicarapun harus baik dan benar agar apa yang hendak di sampaikannya bisa dan mudah di pahami apa maksud penyampaian itu. Menurut Carool, Seefelt \& Barbara A mengnyampaikan pada usia 4 tahun perkembangan kosaskata anak mencapai 4.000-6.000 kata dan berbicara dalam kalimat 5-6 kata. Usia 5 tahun perbendaharaan kata terus bertambah mencapai 5.000 sampai 8.000 kata. Kalimat yang dipakaipun semakin kompleks (Aprinawati, 2017). 
Setiap negara memiliki bahasanya masing-masing. Tampa mengurai rasa patriot nasionalisme terhadap bangsa sendiri. Banyak sekali Bahasa yang perlu kita kenalkan kepada anak itu semua merupakan bagian dari penunjangan anak ketika memasuki dunia luar, agar tidak tertinggal dari negara lain. Adapunbahasa yang salah satu yang sedari kecil biasa orang tua maupuan keluar lainnya mengajarkan kepada anak yaitu bahas ainggris. Bahasa inggris merupakan bagian drai bahasa internasional. Menurut Santrock (2004), bahasa terdiri dari bunyi-bunyian dasar atau fonem. Di dalam bahasa inggris terdapat 36 fonem (Arumsari et al., 2017).

Tidaklah mudah seseorang menguasai bahasa asing yaitu Bahasa Inggris untuk itulah perlu sedini mungkin mengenalkan dan mengajarkan Bahasa Inggris bagi anak. Ada enam (Marno dan Idris, 2009) komponen sangat penting untuk berkembang oleh peserta didik sesuai dengan peraturan menteri no 137 tahun 2014 yaitu aspek moral agama, kognitif, bahasa, sosial emosional dan seni dari beberapa aspek tersebut ada salah satu aspek yang mendukung dalam perkembangan anak yaitu aspek bahasa yang mana aspek tersebut berperan dalam mengembangkan seni dan kreativitas anak (Agus Suprijono, 2010).

Perlu metode yang tepat dalam pemberian pengajaran Bahasa Inggris kepada anak usia dini. Karena perlunya pembelajaran yang tepat itulah bisa membuat anak usia dini bisa menyerap dengan mudah mengenai Bahasa Inggris. Perlunya juga kenyamanan bagi anak usia dini ketika belajar baha Inggris akan membuat anak senang. Hal itupun penting dan perlu di lakukan karena menimbang ketika anak merasakan kesenangan artinya anak tidak merasa tertekan dan menyukai pembelajaran bahasa Inggris.

Kepandaian berbicara dapat dilakukan dengan mengikuti suatu perlakuan yang berperan langsung dan berkarakter here and now, melalui pokok pembahasan berbicara yang rentang dengan aspek berdasarkan konsep tempat (Margarent Silver dkk, 2003). "Total Physical Response (TPR) atau Respon Fisik Total ini merupakan metode pembelajaran bahasa Inggris yang sesuai untuk anak usia dini dimana pembelajarannya lebih mengutamakan kegiatan yang langsung berhubungan dengan kegiatan fisik dan gerakan (Yuli Astutik, 2013). Lebih jelasnya peran anak dalam metode TPR ini adalah untuk mendengarkan dan melakukan hal-hal yang disampaikan guru (Hafidah \& Dewi, 2019). Jack C. Richards And Theodore S. Rodgers di dalam bukunya bahwa TPR is a language teaching method built around the coordination of speech and action, its attems to teach language throughphysical (motor) 
activity. TPR diciptakan oleh Dr. James J. Asher, seorang profesor psikologi di Universitas San Jose, California, Amerika Serikat (Nugraheni, N. E., \& Kristian, 2019).

Pernyataan asher bahwa metode belajar TPR (Eli Tohonan, 2007) "Total Physical Response" merupakan cara belajar di awali melali penerapan kurin hening atau "silen period", berarti dalam kurun ini peserta didik dapat sebuah arti dari jakan yang di samapaikan oleh pendidik, maksud dari tidak adanya metode pemberian arti bahasa yang ada ajarannya, namun metode berbicara menggunakan bahasa tubuh "body langage conveesations" (Berty Segal Cook, 2008). Metode TPR merupakan pengantar untuk pendekatan pengajaran yang dikenal sebagai respon fisik total (Mulyanah et al., 2018). TPR merupakan metode yang populer dalam memperkenalkan kosa kata yang berkenaan dengan suatu tindakan atau gerakan bagi anak usia dini. Kecenderungan masyarakat akan penguasaan bahasa asing tersebut, membuat mereka saling berlomba memasukkan anak-anak mereka untuk mempelajari bahasa Inggris sebagai salah satu keahlian yang dikembangkan. Hal ini berdasarkan asumsi bahwa anak lebih cepat belajar bahasa asing dari pada orang dewasa (Yesi Novitasari, Sri Wahyuni, 2020). Kemampuan bahasa memiliki peranan penting bagi kehidupan individu, khususnya pada anak usia dini (Alam \& Lestari, 2019). Bahasa Inggris merupakan bahasa global yang digunakan oleh bangsa-bangsa yang ada di belahan bumi untuk berkomunikasi antar individu atau masyarakat dunia (Nina Dwiastuty, Doni Anggoro, 2017).

Menurut Larsen dan Freeman, TPR adalah The comprehension approach atau pendekatan pemahaman yakni metode pendekatan bahasa asing dengan perintah atau intruksi. Tarigan juga berpendapat bahwa, dalam metode TPR pemahaman dan ingatan diperoleh dengan baik melalui gerakan tubuh para siswa dalam menjawab atau memberikan response pada perintah-perintah (Yuli Astutik, 2013). Fahrurrozi (2017) yang mengungkapkan bahwa metode TPR merupakan metode yang memberikan penekanan yang lebih besar pada bentuk instruksi perintah yang mudah digunakan oleh guru dan dipahami siswa karena dilakukan dengan cara gerakan tubuh.

Suhendan memaparkan bahwasannya metode TPR sangatlah tepat untuk di laksanakan dalam pembelajaran bahasa bagi anak usia dini yaitu: Pertama. TPR berkaitan dengan karakteristik belajar peserta didik. Pada dasarnya anak-anak perlu untuk bergerak karena mereka memiliki energi yang sangat besar dan memiliki jangkauan perhatian yang pendek/singkat. Interaksi seorang anak yang intens dengan lingkungan sekitar dan anak yang 
memiliki rasa ingin tahu yang besar sehingga perlunya bimbingan mengenai Bahasa anak baik yang bersifat fisik dan nyata. Menurut Scott dan Ytreberg dalam Suhendan bahwasannya hal yang dominan dalam pemahaman anak berasal dari hal-hal yang berkaitan dengan tangan, mata, telinga, dan dunia fisik anak lainnya. Jika aktivitas TPR merupakan sebuah kegiatan permainan, hal itulah tepat bagi anak suai dini yang mempunyai ciri belajar kinestetik. (Hafidah \& Dewi, 2020).

Ada beberapa langkah - langkah dasar yang harus diketahui guru sebelum mengajar menggunakan TPR. ProLiteracy Information Center dalam Nur \& Lucas menjelaskan langkah - langkah dasar dalam TPR yaitu: (a) Guru memilih perintah dan kosakata yang diajarkan; (b) Sebelum sesi pelajaran, gutu membuat daftar perintah lengkap sesuai rencana urutan untuk mengajar; (c) Guru mengumpulkan peralatan, alat peraga, atau gambar yang diperlukan untuk mengatur konteks atau ilustrasi perintah; (d) Jika guru mengajar siswa yang berkelompok, pilih dua atau tiga siswa untuk demostrasi.

Lebih jelasnya dalam pelaksanaan metode TPR (Total Physical Response) ini anak mendengarkan dan melakukan hal - hal yang disampaikan guru. Guru berperan memberikan contoh kepada anak didik dalam bentuk ucapan maupun gerakan kemudian anak-anak didorong untuk berbicara dan bergerak memperagakan ketika mereka sudah siap untuk berbicara, ketika anak ada yang belum paham guru harus siap membantu anak tersebut dan guru juga bertugas dalam pemantauan melihat pencapaian anak didiknya dalam pembelajaran bahasa Inggris. Menurut Rokhayati Kelebihan menggunakan TPR dalam kegiatan belajar bahasa Inggris, yaitu: (a) TPR menyenangkan, banyak dinikamti oleh anak-anak dalam proses belajar mengajar; (b) TPR dapat membantu siswa mengingat kata dan ungkapan bahasa Inggris; (c) TPR dapat diterapkan dikelas besa dan kecil; (d) TPR tidak hanya cocok untuk pelajar muda tetapi juga pelaar dewasa; (e) TPR cocok untuk pelajar yang aktif dikelas (Nuraeni, 2019).

Pelaksanaan TPR bagi anak usia dini menggunakan beberapa aspek metode TPR di dalam kelas maupun di luar kelas pada saat pembelajaran bahasa inggris pada anak usia dini. penggunaan metode TPR akan jauh lebih efektif digunakan oleh para guru pada saat berinteraksi dengan anak usia dini diluar pembelajaran materi bahasa inggris. Artinya di selasela memberikan materi di kelas, guru juga lebih sering berinteraksi dengan anak usia dini dengan mengaplikasikan atau menggunakan metode TPR. Hal ini dapat diketahui bahwa pada 
saat meminta anak usia dini untuk tidak ramai atau tidak berisik dengan berkata "silent please". Ketika metode TPR dilaksanakan secara rutin dan terus-menerus dalam kegiatan sehari-hari di sekolah, anak usia dini akan secara otomatis langsung terlibat dalam bahasa tersebut dan melakukan apa yang diucapkannya. Anak usia dini menyadari bahwa akan memahami banyak hal dan selanjutnya anak usia dini percaya diri untuk belajar bahasa asing.

TPR dapat diaplikasikan untukmengajar dan melatih banyak aspek kebahasaan antara lain: Kosakata yang berhubungan dengan tindakan, Kata kerja untuk menunjukkan waktu (Tenses), Bahasa yang digunakan dalam ruang kelas (classroom language), Perintah atau instruksi, Bercerita. Dalam pembelajaran bahasa Inggris banyak metode dan teknik yang dapat digunakan, diantaranya melalui: (a) Imperative Drill, merupakan kalimat perintah sederhana menggunakan bahasa inggris yang dilakukan secara berulang-ulang agar memperoleh gerakan fisik. Contohnya: saat guru memperagakan dan mengatakan touch your hair, maka siswa akan mengikuti gerakan tersebut. Dalam hal ini siswa dilatih pada kemampuan mendengar (listening) serta menambah kosakata baru; (b) Action Song, merupakan kegiatan mendengarkan lagu juga memperagakannya secara langsung dengan cara Guru menyanyikan terlebih dahulu lagu tersebut kepada siswa agar mereka mengetahui nada yang akan di nyanyikan, Ulangi lagu tersebut dan diikuti gerakan sesuai dengan lagu yang dimainkan, Ajak siswa mengikuti gerakan sesuai lirik lagu. Seperti : lagu head and shoulder. Pada saat lirik lagu "head" maka guru dan siswa langsung memegang kepalanya masingmasing, Tanyakan dan jelaskan arti dari kata-kata setiap lirik kepada siswa, Mainkan lagunya secara berulang dan lakukan kembali bersama siswa sambil memperagakannya. (c) Menggunakan Flash Cards (Kartu-Kartu Bergambar), teknik ini digunakan dengan cara menunjukkan kartu-kartu bergambar dan siswa memperagakan aktivitas yang terdapat pada gambar dengan cara sebagai berikut: Guru menyiapkan beberapa gambar dan kata kerjanya seperti walk, run, sing, dance dan sebagainya, Guru meminta siswa mendengarkan kata yang diucapkan oleh guru lalu siswa mengikuti apa yang diucapkan guru, Guru mencoba mengajak anak mengartikan kata yang terdapat pada gambar dengan cara memperagakannya, Guru menyebutkan kembali kata-kata yang terdapat dalam kartu bergambar lalu siswa memperagakannya, Untuk mengetes konsentrasi anak guru bisa memberikan instruksi dengan mempercepat pengucapan kata sesuai gambar yang ditunjukkan oleh guru. 
1) Role Play (Bermain Peran), merupakan teknik ini yang membuat siswa belajar bahasa dalam berkomunikasi dan mengenal berbagai macam karakter dalam kehidupan nyata dengan menirukan tindakannya. Seperti anak menirukan orang yang sedang marah, senang, dan sedih.

2) Story Telling (Bercerita), dengan bercerita dapat membantu anak-anak memahami bahasa sejak awal yaitu mendengarkan, mengamati, dan meniru. Anak-anak secara bertahap dapat memahami bahasa secara holistik: Games (Permainan), Show and Tell, Music and Movement (Gerak dan Lagu) dimanatermasuk di dalamnya Singing (Nyanyian) dan Chants and Rhymes (Nyanyian Pendek dan Sajak).

Dalam pelaksanaan metode TPR (Total Physical Respone) ini gurupun untuk selalu dan tetap melakukan observasi bagi anak. Hal itupun di maksudkan agar metode ini bisa berjalan sesuai rencana dan perkembangan aspek Bahasa Inggris melalui metode TPR (Total Physical Respone) ini bisa berjalan dengan baik, dan perkembangan Bahasa Inggris anak akan lebih baik pula.

Pada tanggal 11 april peneliti melakukan pra observasi di TK Edelweiss peneliti melihat guru menerangkan pembelajaran bahasa inggris dengan metode klasik yaitu mengingat kosa kata berdasarkan gambar yang disediakan seperti pada tema buah-buahan guru menunjukan gambar jeruk dan siswa mengingat serta menghafal berdasarkan gambar. Dan juga peneliti melakukan tes awal (pra siklus) dari 15 siswa hanya 40,7\% dalam artian belum berkembang pesat setelah diperoleh skor pre test pada pra siklus tersebut maka diberikan lagi perlakuan (treatment) dengan menggunakan metode TPR (Total Physical Respone).

Berdasarkan pertimbangan itu, artikel ini berjudul penerapan metode Total Physical Reapone (TPR) dalam pembelajarah bahasa inggris anak usia dini di TK Edelweiss Kota Jambi. Tujuan penelitian ini adalah untuk mengetahui efektivitas Metode TPR di gubakan untuk belajar berbahasa Inggris peserta didik. Dengan dilakukannya penelitian ini bisa memberikan kontribusi untuk setiap pembaca dari berbagai pihak yang bisa menjadi referensi untuk bahan ajar yang berkaitan dengan metode dan lain-lain yang bisa menjadi sumbangan ide pokok serta pengetahuan bagi berbagai pihak. 
Al Athfaal: Jurnal Ilmiah Pendidikan Anak Usia Dini

Vol.4 No.1 (2021) 137-151

p-ISSN : 2622-5484

http://ejournal.radenintan.ac.id/index.php/al-athfaal

\section{METODE PENELITIAN}

Metode penilitian ini adalah metode penelitian Tindakan kelas. Pada penelitian ini seorang peneliti melakukan penelitiannya di dalam kelas dengan cara observasi objek yang akan di teliti. Penelitian tindakan kelas "classroom achtion research". Sistematika perencanaannya kemmis menggubakan varian spiral refleksi diri pada siklua dalam 3 komponen, termuat: rencana (planning), tindakan (acting), pengamatan (observing), dan refleksi (reflecting) (Wina Sanjaya, 2008). Penelitian Tindakan Kelas mempunyai karaktaristik yang berbeda dengan penelitian yang lain (Ani Widayati, 2008, p. 89). Jenis penelitian ini yaitu Penelitian Tindakan Kelas dengan penggunaan metode eksperimen dengan rancangan “one grup pretest-postteat desaign” (Sugiyono, 2018). Penelitian Tindakan Kelas terdiri dari penelitian, tindakan, dan kelas (Mulia \& Suwarno, 2016, p. 3). Dalam jenis ini adanya pretest ketika sebslum adanya perlakuan dan akan di bandingkan keadaan setelah di berikan perlakuan (posttest). Adapun subjek yang di gunakan pada penelitian ini adalah siswa taman kanak-kanak edelweiss Kota Jambi, di kelas sun kelas B dengan jumlah 15 anak yang di asuh oleh guru leni.

\section{HASIL DAN PEMBAHASAN}

\section{A. Hasil}

Perlu adanya sampel dalam penelitian ini, sampel adalah Sebagian dari populasi. Biasasnya sampel hanya Sebagian dai populasi atau keseluluhan objek yang di jadikan penelitian. Sampel erat kaitannya dengan populasi, populasi yanag merupakan keseluruhan objek penelitian. Dalam hal ini Pengambilan sampel dengan teknik ini yaitu sampling jenuh, meruoakan samplenya sebagai penentu atas populasi yang di jadikan sample (Anas Sudijono, 2006). Adanya soranerinh di perlakukan saat jumlah populasi sangat kecil yaitu 30 peserta didik ke bawah (Sugiyono, 2018). Penelitian ini sampelnya adalah kelompok B1 sebanyak 15 peserta didik.

Berdasarkan itu semua adanya penerusan pada siklus II. Dilaksanakannya itu akibat musyawarah seorang peneliti dengan kombinasasi atas pertimbangan kemampuan bahasa peserta didik bertingkat sama harapan yang sudah di fikirkan melalui perbaikan atas kekurangan di siklus I supaya lebih optimal. Meningkatkan kemampuan bahasa anak pada siklus I dan II juga disajikan pada diagram berikut: 
Al Athfaal: Jurnal Ilmiah Pendidikan Anak Usia Dini

Vol.4 No.1 (2021) 137-151

p-ISSN : 2622-5484

http://ejournal.radenintan.ac.id/index.php/al-athfaal

Hasil observasi Peningkatan kemampuan bahasa anak dengan menggunakan penerapan metode TPR pada setiap pertemuan adalah sebagai berikut: Diagram Persentase peningkatan kemampuan bahasa anak dengan menggunakan penerapan metode TPR

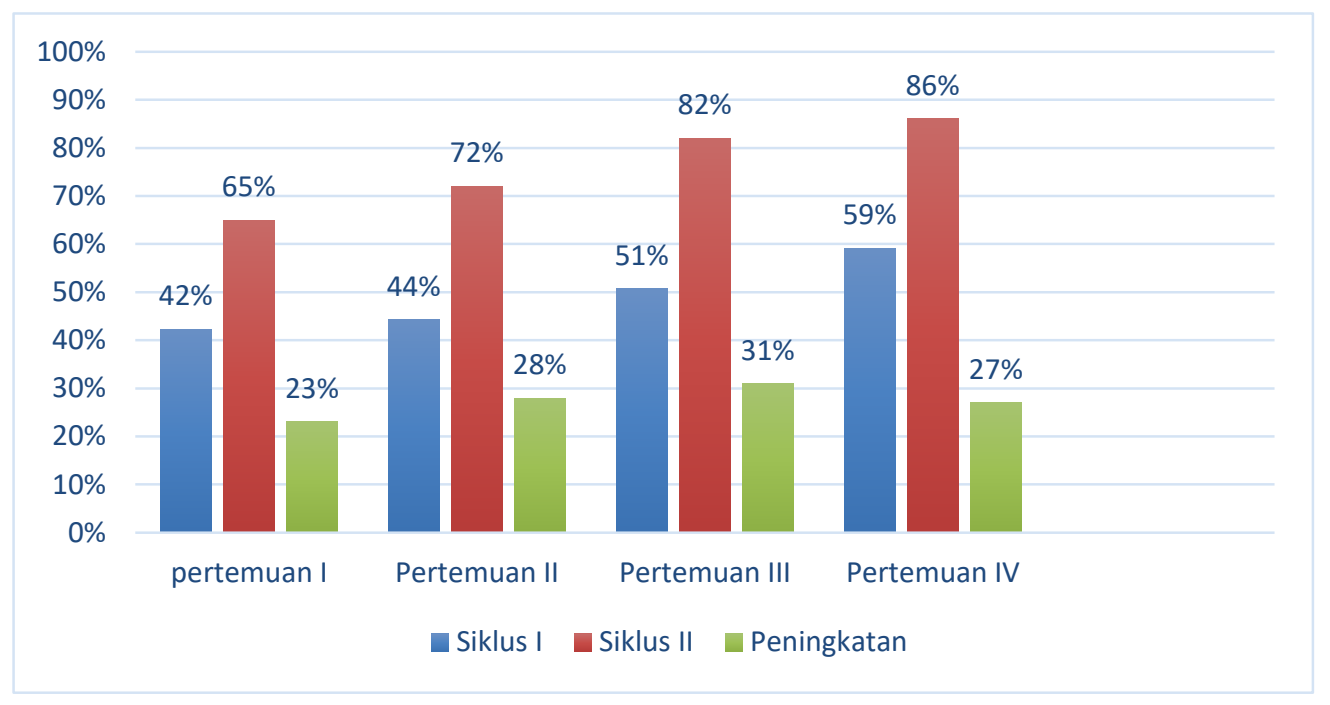

Gambar. Grafik Persentase Peningkatan Metedo TPR

Perolehan nilai observasi rata-rata peningkatan bahasa peserta didik siklus 1 mendapatkan skor $409 \%$ terus membaik dilaksanakan siklus 2 memperoleh $7625 \%$. Oleh sebab itu disimpulkan Penerapan metode TPR bisa meningkatkan kemampuan bahasa pada peserta didik di taman kanak-kanak edelweis Kota Jambi

\section{B. Pembahasan}

Pada hasil dari penerapan metode TPR anak-anak tampak terlihat antusias dalam mengutarakan pendapatnya dan menggunakan bahasanya secara lisan, serta mengulang/menceritakan kembali TPR. Berbekal penjelasan yang telah diberikan di dalam kelas, anak-anak mulai menyukai dan berani untuk mengexpresikan idenya dengan TPR. Selain itu dari hasil observasi selama penelitian di Taman Kanak-kanak Edelweissh kota Jambi kelas B1, terlihat sangat jelas bagaimana keaktifan dan peningkatan bahasa anak sesudah dans sebelum diterapkanya metode TPR ini. Seperti terlihat bahwa keaktifan anak terdapat perubahan Pada siklus 1 kemudian siklus 2 pemerolehan nilai belajar akhir Pada siklus 1 tercapai 42,30\% menjadi $86 \%$ yang termuat pada ada siklus 2 akhir. Skor rata-rata anak periode siklus 1 berada dalam kategori mulai berkembang dan semakin meningkat pada siklus 2 dengan rata-rata anak berada pada ada kategori berkembang sesuai harapan titik berdasarkan analisis hasil observasi peningkatan kemampuan bahasa peserta didik di TK 
Al Athfaal: Jurnal Ilmiah Pendidikan Anak Usia Dini

Vol.4 No.1 (2021) 137-151

p-ISSN : 2622-5484

http://ejournal.radenintan.ac.id/index.php/al-athfaal

edelweis kota Jambi memperoleh peningkatan sesuai indikator. Kesimpulannya yaitu Penerapan metode TPR bisa meningkatkan kemampuan bahasa peserta didik Pada usia 5-6 tahun di TK edelweis Kota Jambi.

\section{SIMPULAN DAN SARAN}

Perolehan telaah yang bisa di landaskan yaitu pembelajaran bahasa inggris peserta didik pada kelompok B TK edelwiss kota jambi mampu memperoleh peningkatan dalam cara TPR. Hal itu dapat di perolwh dari peningkatan persentase intelektual interoersonal, dalam kegiatan pra observasi menunjukkan hal $24 \%$ memperoleh dengan meningkat pada siklus 1 dengan perolehan nilai 23\% menjadi 47\%. Dilain sisi memasuki siklus II memperoleh dengan meningkat $20 \%$ menjadi $87 \%$. Langkah-langkah pembelajaran yang ditempuh dalam metode total physical respone adalah sebagai berikut:metode tersebut dengan menggunakan 3 tahap yaitu mendengar,menulis dan demonstrasi guru menggerakan tangan dan siswa meniru selanjutnya guru memrintah siswa dengan ucapan lalu siswa mulai bergerak. Pada hasil dari penerapan metode TPR anak-anak tampak terlihat antusias dalam mengutarakan pendapatnya dan menggunakan bahasanya secara lisan, serta mengulang/menceritakan kembali TPR. Berbekal penjelasan yang telah diberikan di dalam kelas, anak-anak mulai menyukai dan berani untuk mengexpresikan idenya dengan TPR.

Adapun saran berdasarkan hasil penelitian dan pembahasan pelaksaan tindakan terkait tentang pembelajaran bahasa inggris melalui metode total physical respone yakni memperkenalkan serta menerapkan cara TPR agar anak mengetahui bahasa inggris melalui gerak isyarat dan perintah, adanya perkembangan dari segi rencan dalam peningkatan intelektual berbahasa inggrus peserta didik berbahasa inggris anak, serta kegiatan pembelajaran lain yang menunjang anak untuk mengenal bahasa asing, Pemakaian acara TPR di harapkan mampu meningkatkan anak dalam berbahasa inggris, masih adanya ke tertinggalan dalam hal tersebut. Sebab itulah, perlunya telaah yang mampu membangun semangat dalan meneruskan telahh ini dalam penggunaan cara belajar dengan media belajar yang menarik dalam peningkatan bahasa inggris peserra didik. 
Al Athfaal: Jurnal Ilmiah Pendidikan Anak Usia Dini

Vol.4 No.1 (2021) 137-151

p-ISSN : 2622-5484

http://ejournal.radenintan.ac.id/index.php/al-athfaal

\section{UCAPAN TERIMA KASIH}

Terima kasih kepada sekolah TK Edelweiss Kota Jambi yang telah bekerja sama dengan peneliti dalam menyelesaikan penelitian ini.

\section{DAFTAR PUSTAKA}

Agus Suprijono. (2010). Cooperative Learning Teori dan Aplikasi PAIKEM. Yogyakarta: Pustaka Pelajar.

Alam, S. K., \& Lestari, R. H. (2019). Pengembangan Kemampuan Bahasa Reseptif Anak Usia Dini dalam Memperkenalkan Bahasa Inggris melalui Flash Card. Jurnal Obsesi : Jurnal Pendidikan Anak Usia Dini, 4(1), 284. https://doi.org/10.31004/obsesi.v4i1.301

Anas Sudijono. (2006). Pengantar Statistik Pendidikan. Jakarta: PT Raja Grafindo.

Ani Widayati. (2008). Penelitian Tindakan Kelas. Jurnal Pendidikan Akuntansi Indonesia, VI(1), 87-93. https://doi.org/https://doi.org/10.21831/jpai.v6i1.1793

Aprinawati, I. (2017). Penggunaan Media Gambar Seri Untuk Meningkatkan Kemampuan Berbicara Anak Usia Dini. Jurnal Obsesi : Jurnal Pendidikan Anak Usia Dini, 1(1), 72. https://doi.org/10.31004/obsesi.v1i1.33

Arumsari, A. D., Arifin, B., \& Rusnalasari, Z. D. (2017). Pembelajaran Bahasa Inggris pada Anak Usia Dini di Kec Sukolilo Surabaya. Jurnal PG-PAUD Trunojoyo : Jurnal Pendidikan Dan Pembelajaran Anak Usia Dini, 4(2), 133.

https://doi.org/10.21107/jpgpaud.v4i2.3575

Berty Segal Cook. (2008). The Total Physical Response, know world-wide as TPR Bambang Warsita Bambang. Teknologi Pembelajaran, Landasan dan Aplikasinya,. Jakarta: Rineka Cipta. https://doi.org/http:www.tprsource.com/asher.htm. (diakses 28 Mei 2018)

Dewi, K. (2017). Pentingnya Media Pembelajaran untuk Anak Usia Dini. Raudhatul Athfal, 1. https://doi.org/https://doi.org/10.19109/ra.v1i1.1489

Dimyati dan Mudjiono. (2010). Belajar dan Pembelajaran. Jakarta: Rineka Cipta.

Eli Tohonan. (2007). Metode Total Physical Response dalam Pembelajaran Bahasa Inggris. https://doi.org/http://www.bpplsp-reg-1.go.id/buletin/ read.php. (diakses tanggal 20 Mei 2018)

Fahrurrozi. (2017). Improving Students Vocabulary Mastery by Using Total Physical Response English Language Teaching.

https://doi.org/https://doi.org/10.5539/elt.v10n3p118

Hafidah, R., \& Dewi, N. K. (2019). Metode Tpr ( Total Physical Response ) Dalam Pembelajaran. 393-399. https://doi.org/http://dx.doi.org/10.31851/pernik.v3i2.4818

Hafidah, R., \& Dewi, N. K. (2020). TPR ( Total Physical Response ) Method on Teaching. In Early Childhood Education and Development (Vol. 2, Issue 1).

https://doi.org/https://doi.org/10.20961/ecedj.v2i1.45167

Herdyastika, M., \& Kurniawan, M. (2020). Analisis Perbandingan Implementasi Metode Pembelajaran Bahasa Inggris Inovatif di Taman Kanak-Kanak. Jurnal Obsesi: Jurnal Pendidikan Anak ..., 5(2), 1585-1593. https://doi.org/10.31004/obsesi.v5i2.902

Isjoni. (2009). Pembelajaran Kooperatif. Yogyakarta: Pustaka Pelajar.

Kartini \& Sujarwo. (2014). Penggunaan Media Pembelajaran Plastisin Untuk Meningkatkan Kreativitas Anak Usia. Jurnal Pendidikan Dan Pemberdayaan Masyarakat, 1(2), 200. 
Al Athfaal: Jurnal Ilmiah Pendidikan Anak Usia Dini

Vol.4 No.1 (2021) 137-151

p-ISSN : 2622-5484

http://ejournal.radenintan.ac.id/index.php/al-athfaal

https://doi.org/https://doi.org/10.21831/jppm.v1i2.2689

Margarent Silver dkk. (2003). The Total Physical Response (Or TPR).

https://doi.org/http:www.tpr_world.com/asher.htm. (diakses tanggal 29 Mei 2018)

Marno dan Idris. (2009). Strategi \& Metode Pengajaran. Yogyakarta: Ar-Ruzz Media.

Mulia, D. S., \& Suwarno. (2016). PTK (Penelitian Tindakan Kelas) Dengan Pembelajaran

Berbasis Kearifan Lokal Dan Penulisan Artikel Ilmiah Di SD Negeri Kalisube,

Banyumas. Khazanah Pendidikan Jurnal Ilmiah Kependidikan, IX(2), 11.

https://doi.org/http://dx.doi.org/10.30595/jkp.v9i2.1062

Mulyanah, E. Y., Ishak, I., \& Firdaus, M. I. (2018). Penerapan Metode Total Physical

Response (TPR) Dalam Penguasaan Kosa Kata Bahasa Inggris Sekolah Dasar (SD).

Jurnal Pendidikan Sekolah Dasar, 4(2), 175. https://doi.org/10.30870/jpsd.v4i2.3855

Nina Dwiastuty, Doni Anggoro, T. A. (2017). Pembelajaran Bahasa Inggris Melalui Metode

Total Physical Response (TPR). Jurnal Ilmiah Kependidikan, 2(4), 200.

https://doi.org/10.32493/informatika.v2i4.1441

Nugraheni, N. E., \& Kristian, L. D. (2019). Penerapan Metode Total Physical Response

(TPR) untuk Meningkatkan Keterampilan Kosakata Bahasa Inggris bagi Siswa

Tunagrahita. Jurnal Lingua Applicata, 2(1).

https://doi.org/https://doi.org/10.22146/jla.35177

Nuraeni, C. (2019). Promoting Total Physical Response (TPR) Method On Early Childhood

English Language Teaching. Jurnal Penelitian Humaniora, 20(2), 67-79.

https://doi.org/10.23917/humaniora.v20i2.7144

Oemar Hamalik. (2010). Psikologi Belajar Mengajar. Bandung: Sinar Baru Algensindo.

Pratiwi, D. D., Mujib, Andriani, S., Mardiyah, Kuswanto, C. W., \& Utami, E. (2021).

Application of algebraic tile media with gasing: Ability to understand mathematical concepts and student creativity. IOP Conference Series: Earth and Environmental Science, 1796(1). https://doi.org/10.1088/1742-6596/1796/1/012023

Rohmah, U. (2018). Pengembangan Karakter Pada Anak Usia Dini (AUD). Al-Athfal : Jurnal Pendidikan Anak, 4(1), 85-102. https://doi.org/10.14421/al-athfal.2018.41-06

Sugiyono. (2018). Metode Penelitian Pendidikan (Pendekatan Kuantitatif, Kualitatif, dan $R \& D)$. Alfabeta.

Suyanto S. (2005). Pembelajaran Untuk Anak TK. Jakarta: Depdiknas.

Wina Sanjaya. (2008). Kurikulum dan Pembelajaran, Teori dan Praktek Pengembangan

Kurikulum Tingkat Satuan Pendidikan (KTSP). Jakarta: Kencana.

Yesi Novitasari, Sri Wahyuni, S. R. (2020). Meningkatkan Kemampuan Bahasa Inggris Awal

Melalui Metode Total Physical Response pada Anak Usia Dini. Pengelolaan Kelas Pada Model Pembelajaran Kelompok Pada Anak Usia 5-6 Tahun Di TK IT Al-Mahira, 3(2), 68-77. https://doi.org/https://doi.org/10.31849/paud-lectura.v3i02.3852

Yuli Astutik, \& C. N. A. (2013). Metode Total Physical Response (TPR) Pada Pengajaran Bahasa Inggris Siswa Taman Kanak-Kanak. Jurnal Pendidikan Bahasa Dan Sastra, 13(2), 102-117. https://doi.org/10.17509/bs 